\title{
PERANCANGAN ENTERPRISE ARCHITECTURE PADA FUNGSI KESEHATAN MASYARAKAT DI DINAS KESEHATAN KABUPATEN BANDUNG MENGGUNAKAN TOGAF ADM
}

\author{
${ }^{1}$ Risna Purwita Siwi, ${ }^{2}$ Rohmat Saedudin, ${ }^{3}$ Ridha Hanafi \\ 1,2,3Program Studi Sistem Informasi, Fakultas Rekayasa Industri, Telkom University \\ risnasiwi1412@gmail.com, ${ }^{2}$ roja2128@gmail.com, ${ }^{3}$ ridhanafi@gmail.com
}

\begin{abstract}
Abstrak-Perkembangan bisnis dan teknologi yang seimbang akan mendukung organisasi/perusahaan untuk mencapai tujuan dengan maksimal. Untuk itu diperlukan enterprise architecture yang menjamin keselarasan antara strategi bisnis dan teknologi informasi perusahaan sehingga terintegrasi dengan kebutuhan bisnis serta mendapat dukungan TI perusahaan. Dinas Kesehatan Kabupaten Bandung mempunyai misi yaitu memberikan pelayanan kesehatan berkualitas kepada masyarakat. Oleh karena itu, diperlukan peningkatan layanan-layanan yang mendukung aktivitas bisnis Dinas Kesehatan Kabupaten Bandung salah satunya adalah layanan informasi masyarakat yang dinilai kurang efektif. Pendekatan yang dilakukan dalam merancang sistem untuk layanan informasi masyarakat yaitu menggunakan penerapan enterprise architecture. Enterprise architecture dapat menjadi metode untuk merancang solusi sistem dan teknologi informasi sesuai dengan arahan bisnis. Perancangan EA pada penelitian ini menggunakan TOGAF ADM. TOGAF ADM memiliki kerangka serta metodologi yang lengkap dan dapat mendukung seluruh proses pengembangan enterprise architecture.
\end{abstract}

Kata kunci: Enterprise architecture, TOGAF ADM, dinas kesehatan

\section{PENDAHULUAN}

Teknologi Informasi (TI) adalah suatu teknologi yang digunakan untuk mengolah data, termasuk memproses, mendapatkan, menyusun, menyimpan, memanipulasi data dalam berbagai cara untuk menghasilkan informasi yang berkualitas, yaitu informasi yang relevan, akurat dan tepat waktu, yang digunakan untuk keperluan pribadi, bisnis, dan pemerintahan dan merupakan informasi yang strategis untuk pengambilan keputusan [1]. Implementasi TI diharapkan dapat mendukung efektifitas dan efisiensi dalam mencapai tujuan organisasi atau perusahaan. Sehingga banyak perusahaan yang melakukan transformasi baik dari sisi proses bisnis sampai sistem informasinya.

Dinas Kesehatan Kabupaten Bandung merupakan Dinas Otonomi Daerah yang secara struktur sepenuhnya berada dalam kewenangan pemerintah daerah, sedangkan hubungan dengan Dinas Kesehatan Propinsi adalah merupakan hubungan kerja fungsional, sehingga tugas-tugas bantuan (dekonsentrasi) di fungsi kesehatan di tingkat kabupaten dapat berjalan dengan yang diharapkan [2].

Dinas Kesehatan Kabupaten Bandung memiliki visi yaitu terwujudnya masyarakat kabupaten Bandung yang sehat mandiri. Salah satu misi untuk mendukung visi tersebut adalah memberikan pelayanan kesehatan berkualitas kepada masyarakat. Oleh karena itu, diperlukan peningkatan layanan-layanan yang mendukung aktivitas bisnis di Dinas Kesehatan Kabupaten Bandung. Salah satu aktivitas bisnis yang perlu dikembangkan adalah layanan rujukan dan informasi masyarakat Dinas Kesehatan Kabupaten Bandung yang menggunakan sistem call center. Kekurangan pada layanan rujukan adalah alur proses yang tidak efektif karena puskesmas harus menanyakan ke dinas kesehatan tentang ketersediaan kamar di rumah sakit sebelum pasien dirujuk. Layanan informasi masyarakat juga dinilai kurang efektif karena belum dapat menampilkan secara visual informasi kesehatan yang dibutuhkan. Akan bermanfaat jika terdapat aplikasi layanan informasi kesehatan berbasis mobile yang dapat dengan mudah diakses oleh masyarakat. Sehingga pelayanan kesehatan terhadap masyarakat menjadi maksimal dan diharapkan dapat meningkatkan kepuasan masyarakat.

Permasalahannya adalah bagaimana menyelaraskan strategi bisnis dan strategi TI di Dinas Kesehatan Kabupaten Bandung sehingga dapat meningkatkan kepuasan masyarakat terhadap pelayanan kesehatan. Untuk itu diperlukan enterprise architecture yang menjamin keselarasan antara strategi bisnis dan teknologi informasi perusahaan sehingga terintegrasi dengan kebutuhan bisnis serta mendapat dukungan TI perusahaan. Enterprise architecture merupakan salah satu metode yang dapat digunakan untuk menyelarasakan strategi bisnis dan strategi teknologi informasi yang dirancang sesuai dengan kebutuhan bisnis [3].

Dalam merancang sistem untuk layanan rujukan dan informasi masyarakat, Dinas Kesehatan Kabupaten Bandung perlu memperhatikan berbagai macam aspek di dalamnya, seperti penggunaan teknologi informasi yang tepat dan sesuai dengan strategi bisnis layanan. Tetapi aktivitas bisnis biasanya berkembang lebih cepat dibandingkan dengan perkembangan teknologi informasi. Sehingga hal tersebut mengakibatkan layanan rujukan dan informasi masyarakat tidak dapat terlaksanan secara optimal. Maka dari itu, dalam pengembangan bisnis dan teknologi informasi dibutuhkan perencanaan dan perancangan yang tepat. Salah satu pendekatan yang dapat dilakukan dalam merancang sistem untuk layanan rujukan dan informasi masyarakat yaitu menggunakan penerapan enterprise architecture.

Enterprise architecture dapat menjadi salah satu metode untuk merancang solusi sistem dan teknologi informasi sesuai dengan arahan bisnis. Pada penelitian ini, perancangan enterprise architecture menggunakan TOGAF ADM. TOGAF merupakan framework arsitektur yang dikembangkan oleh Open Group. TOGAF memiliki kerangka serta metodologi yang lengkap dan dapat mendukung seluruh proses pengembangan enterprise architecture [4]. 


\section{TINJAUAN PUSTAKA}

\section{A. Enterprise Architecture}

Enterprise Architecture (EA) merupakan pendekatan untuk menganalisis dan menyusun pengetahuan organisasi ke dalam rencana bisnis strategis sehingga dapat membantu dalam pengambilan keputusan strategis [5]. EA sebagai strategi dukungan organisasi semakin sering digunakan untuk menggambarkan integrasi bisnis, manajemen informasi, dan teknologi informasi di perusahaanperusahaan yang kompleks. Tujuan dari EA adalah memberikan pandangan organisasi yang memungkinkan executives, manajer bisnis, arsitek, insinyur, dan teknisi untuk koheren mengkoordinasikan dan mengintegrasikan aktivitas mereka [6].

Perusahaan memanfaatkan enterprise architecture untuk memberikan solusi yang tepat untuk kebutuhan bisnis mereka. Dalam proyek EA, perusahaan harus menentukan framework dan metodologi pelaksanaan. Framework adalah dasar pengorganisasian untuk arsitektur referensi dan domain arsitektur serta ilmu yang memungkinkan pemecahan permasalahan teknologi informasi untuk penyelarasan bisnis [7].

Terdapat beberapa framework yang mendukung pemodelan dan pengembangan EA seperti Zachman Framework (ZF), The Open Group Architecture Framework (TOGAF), dan Federal Enterprise Architecture Framework (FEAF). Untuk memilih pendekatan yang terbaik, dapat dinilai mana enterprise architecture framework yang memiliki kemampuan untuk mencapai kebutuhan arsitektur. Dalam prakteknya, EA framework tidak ada yang sempurna karena masingmasing memiliki kelebihan dan kekurangan, serta penggunaan di masing-masing organisasi/perusahaan bisa menjadi berbeda [8].

\section{B. TOGAF ADM}

TOGAF Architecture Development Method (ADM) menggambarkan suatu metode untuk mengembangkan dan mengelola siklus hidup suatu enterprise architecture dan membentuk inti dari TOGAF [9]. TOGAF ADM menyediakan proses-proses untuk membangun arsitektur yang mencakup pembangunan framework arsitektur, pengembangan konten, transisi, dan pengaturan/pengendalian terhadap realisasi arsitektur. Semua aktivitas tersebut dilakukan dalam sebuah siklus yang berulang dan berkelanjutan.

TOGAF ADM terdiri dari beberapa fase yang menerapkan langkah-langkah pembuatan enterprise architecture. Fase-fase tersebut yaitu:
a. Preliminary Phase
b. Phase A: Architecture Vision
c. Phase B: Business Architecture
d. Phase C: Information System Architecture
e. Phase D: Technology Architecture
f. Phase E: Opportunities \& Solutions
g. Phase F Migration Planning
h. Phase G: Implementation Governance
i. Phase H: Architecture Change Management

III. METODOLOGI PENELITIAN

\section{A. Model Konseptual}

Penelitian ini menggunakan model konseptual sebagai metodenya. Model konseptual merupakan gambaran yang dibuat berdasarkan teori dan hipotesis yang berkaitan dengan penelitian yang sedang dilakukan. Model ini digunakan sebagai kerangka berpikir yang menjelaskan konsep secara terstruktur dari penelitian untuk menghasilkan output yang sesuai dengan tujuan penelitian.

Dalam perancangan enterprise architecture ini diadasari oleh permasalahan yang terdapat pada lingkungan Dinas Kesehatan Kabupaten Bandung dimana sistem informasi belum saling terintegrasi dan aplikasi yang ada belum dimanfaatkan secara maksimal serta terdapat sistem yang masih menggunakan cara manual. Pelaku yang terlibat dalam lingkungan tersebut adalah pegawai Dinas Kesehatan Kabupaten Bandung, pegawai puskesmas, pegawai rumah sakit, dan masyarakat. Dinas Kesehatan Kabupaten Bandung dapat mengembangkan strategi bisnis melalui rencana strategis, visi dan misi, serta SOP (Standard Operational Procedure). Dalam penelitian ini menggunakan konsep perancangan enterprise architecture menggunakan TOGAF ADM dan hasil dari penelitian yang berjudul Perancangan Enterprise Architecture pada Fungsi Kesehatan Masyarakat di Dinas Kesehatan Kabupaten Bandung Menggunakan TOGAF ADM. Untuk memperkuat konsep tersebut, dilakukan wawancara dan observasi untuk mengetahui informasi yang diperlukan pada penelitian.

Penelitian ini menghasilkan blueprint atau rancangan masingmasing arsitektur dalam TOGAF ADM, yaitu preliminary phase, architecture vision, business architecture, data architecture, application architecture, technology architecture, opportunities and solutions, dan migration planning. Perancangan tersebut akan menggunakan analisis sebagai fase evaluasi.

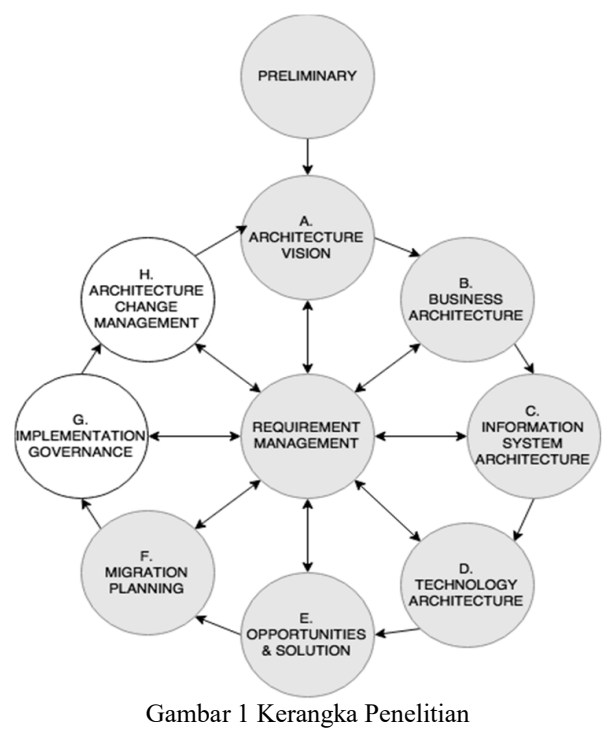

B. Kerangka Kerja

Penelitian ini dilakukan pada suatu dinas di Pemerintah Kabupaten Bandung yaitu Dinas Kesehatan Kabupaten Bandung. Penelitian ini berupa perancangan arsitektur meliputi business architecture, information system architecture, technology 
architecture, opportunities and solutions, dan migration planning yang didasarkan pada tahapan kerangka kerja TOGAF ADM.

\section{HASIL DAN PEMBAHASAN}

Perancangan enterprise architecture dibuat berdasarkan TOGAF ADM. Perancangan terdiri dari beberapa arsitektur, diantaranya adalah business architecture, data architecture, application architecture, technology architecture, opportunities and solutions, dan migration planning.

\section{A. Preliminary Phase}

Preliminary phase atau disebut juga fase persiapan, merupakan fase awal pada TOGAF ADM. Di dalam fase ini berisi suatu prinsip tentang bagaimana melakukan perencanaan dan perancangan enterprise architecture. Prinsip tersebut digunakan sebagai tolak ukur dalam menilai keberhasilan perancangan enterprise architecture oleh suatu organisasi. Prinsip-prinsip arsitektur didefinisikan dalam fase ini dalam bentuk principle catalog dari masing-masing arsitektur seperti business architecture, data architecture, application architecture, dan technology architecture berdasarkan prinsip-prinsip bisnis yang ada di suatu perusahaan. Principle catalog menggambarkan solusi dan seperti apa arsitektur yang seharusnya.

TABEL I

PRINCIPLE CATALOG

\begin{tabular}{|c|c|}
\hline Kategori Principle & Principle \\
\hline \multirow{9}{*}{ Business principle } & Penggunaan aplikasi umum \\
\hline & Layanan orientasi \\
\hline & $\begin{array}{l}\text { Kepatuhan hukum dan regulasi } \\
\text { lainnya }\end{array}$ \\
\hline & Tanggung jawab IT \\
\hline & Keutamaan prinsip \\
\hline & Keberlangsungan bisnis \\
\hline & $\begin{array}{l}\text { Memaksimalkan pemanfaatan } \\
\text { enterprise }\end{array}$ \\
\hline & Efektivitas dan efisiensi \\
\hline & Pelaporan data yang sistematis \\
\hline \multirow{6}{*}{ Data principle } & Data adalah aset \\
\hline & Sharing data \\
\hline & Data dapat diakses \\
\hline & Keamanan data \\
\hline & Data up-to-date \\
\hline & Integrasi data \\
\hline \multirow{3}{*}{ Application principle } & User-friendly \\
\hline & Kehandalan aplikasi \\
\hline & Akses mudah \\
\hline \multirow{6}{*}{ Technology principle } & Fleksibilitas aplikasi \\
\hline & Keamanan teknologi \\
\hline & Interoperability \\
\hline & $\begin{array}{l}\text { Perubahan teknologi sesuai } \\
\text { kebutuhan }\end{array}$ \\
\hline & Pemanfaatan aset IT \\
\hline & Real-time \\
\hline
\end{tabular}

B. Architecture Vision
Architecture vision merupakan fase awal dari TOGAF ADM. Dalam fase ini digambarkan pendefinisian ruang lingkup dan identifikasi stakeholder dari arsitektur yang akan dirancang. Fase ini menghasilkan beberapa artifact yaitu stakeholder map matrix, value chain diagram, dan solution concept diagram.

Stakeholder map matrix mendeskripsikan pihak-pihak yang terlibat dan yang bertanggung jawab dengan semua aktivitas bisnis pada Dinkes Kabupaten Bandung. Stakeholder map matrix pada fungsi kesehatan masyarakat terdiri dari 22 stakeholder internal dan 5 stakeholder eksternal.

Value chain diagram bertujuan untuk mendeskripsikan fokus tujuan perusahaan, aktivitas-aktivitas utama (primary activities), dan aktivitas-aktivitas pendukung (support activity) perusahaan. Pada Dinas Kesehatan Kabupaten Bandung, yang menjadi fokus tujuan adalah kepuasan masyarakat, dimana misinya adalah memberikan pelayanan kesehatan berkualitas kepada masyarakat. Aktivitas utama terdiri dari perencanaan, pelaksanaan, pelaporan, publikasi \& sosialisasi, dan pelayanan masyarakat. Aktivitas pendukung terdiri dari keuangan, kepegawaian, pengadaan, dan teknologi informasi.

Solution concept diagram menunjukkan konsep solusi kebutuhan bisnis secara high-level atau global. Penggambaran solution concept diagram Dinas Kesehatan Kabupaten Bandung ditunjukkan pada Gambar 2.

\section{Business Architecture}

Perancangan business architecture merupakan fase kedua pada TOGAF ADM. Fase ini bertujuan untuk mendefinisikan aktivitas bisnis yang ada di suatu organisasi/perusahaan. Selain itu, pada fase ini dilakukan analisis arsitektur bisnis yang berjalan untuk menggambarkan kondisi eksisting di fungsi Kesehatan Masyarakat Dinas Kesehatan Kabupaten Bandung.

Fase ini menghasilkan beberapa artifact yaitu: organization/actor catalog, driver/goal/objective catalog, business service/function catalog, business interaction matrix, actor/role matrix, business footprint diagram, functional decomposition diagram, dan process flow diagram.

Organization/actor catalog berfungsi untuk menjelaskan seluruh aktor yang berinteraksi dengan Dinas Kesehatan Kabupaten Bandung dalam menjalankan aktivitas bisnisnya. Driver/goal/objective catalog dilakukan dengan mendeskripsikan driver, goal, serta objective yang dimiliki oleh fungsi kesehatan masyarakat Dinas Kesehatan Kabupaten Bandung. Business service/function catalog digunakan untuk mengidentifikasi kemampuan suatu organisasi yang diperlukan untuk mendukung perubahan bisnis, aplikasi, dan teknologi. Tabel II merupakan daftar layanan-layanan berdasarkan fungsi kesehatan masyarakat di Dinas Kesehatan Kabupaten Bandung.

Business interaction matrix bertujuan untuk menggambarkan interaksi antar business function yang ada pada Dinas Kesehatan Kabupaten Bandung. Memahami interaksi bisnis pada suatu organisasi/perusahaan itu penting karena membantu menyoroti value chain dan ketergantungan antar organisasi.

Actor/role matrix merupakan pemetaan antara stakeholder dengan aktivitas operasional dari Dinas Kesehatan Kabupaten Bandung. Pemetaan tersebut menggunakan RACI Chart yang berfungsi untuk menunjukkan peran dan tanggung jawab dari aktor yang menjalankan aktivitas pada fungsi bisnis. 


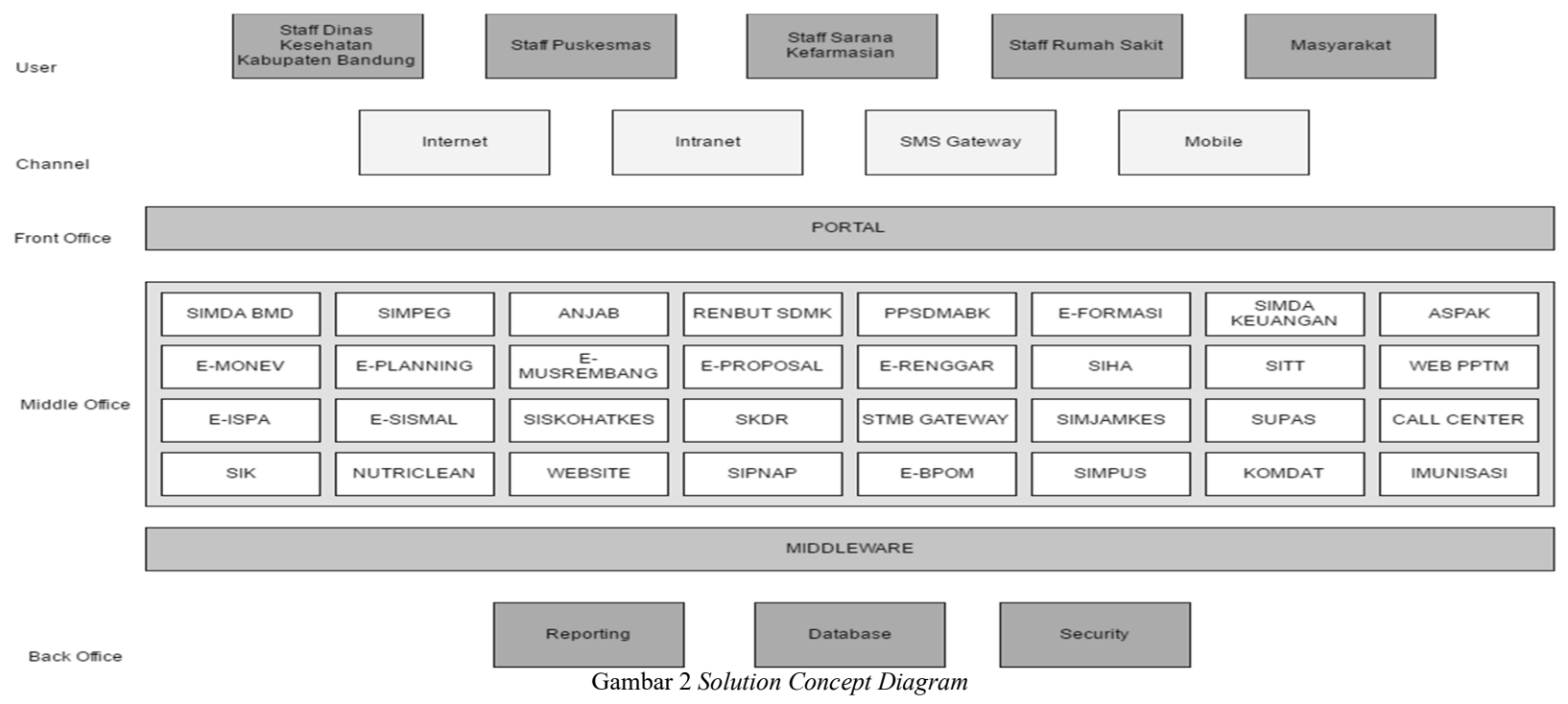

TABEL II

BUSINESS SERVICE/FUNCTION CATALOG

\begin{tabular}{|c|c|}
\hline $\begin{array}{c}\text { No. } \\
\text { Fungsi }\end{array}$ & Nama Fungsi \\
\hline \multicolumn{2}{|c|}{ Primary Activity } \\
\hline 1 & Kesehatan Masyarakat \\
\hline 1.1 & Administrasi Umum \\
\hline 1.1 .1 & Administrasi Umum \\
\hline 1.2 & Pelaksanaan Evaluasi Program \\
\hline 1.2 .1 & Pelaksanaan Evaluasi Program \\
\hline 1.3 & Pengadaan Sarana \& Prasarana Kesehatan \\
\hline 1.3 .1 & Pengadaan Sarana \& Prasarana Kesehatan \\
\hline 1.4 & Pengembangan SDM \\
\hline 1.4 .1 & Pengembangan SDM \\
\hline 1.5 & Pemberdayaan Masyarakat \\
\hline 1.5 .1 & Pengelolaan Pemberdayaan Masyarakat \\
\hline 1.6 & Penyuluhan Masyarakat \\
\hline 1.6 .1 & Pengelolaan Program KB \\
\hline 1.6 .2 & Pengelolaan Program Anak \\
\hline 1.6 .3 & Pengelolaan Program Lansia \\
\hline 1.6 .4 & Pengelolaan Program UKS \\
\hline 1.7 & Penyusunan Rencana \& Promosi \\
\hline 1.7 .1 & Penyusunan Rencana \& Promosi \\
\hline 1.8 & Layanan Rujukan \\
\hline 1.8 .1 & Pengelolaan Program Ibu \\
\hline 1.9 & Pengelolaan Gizi Anak \\
\hline 1.9 .1 & Analisis Gizi \\
\hline 1.9 .2 & Program Peningkatan Gizi \\
\hline 1.9 .3 & Pencegahan dan Penangguhan Masalah Gizi \\
\hline 1.9 .4 & Pelayanan Konsultasi Gizi \\
\hline 1.10 & Layanan Informasi Kesehatan \\
\hline 1.10 .1 & Layanan Informasi Kesehatan \\
\hline \multicolumn{2}{|c|}{ Support Activity } \\
\hline 2 & Keuangan \\
\hline 2.1 & Administrasi Keuangan \\
\hline
\end{tabular}

\begin{tabular}{|c|l|}
\hline $\begin{array}{c}\text { No. } \\
\text { Fungsi }\end{array}$ & \multicolumn{1}{c|}{ Nama Fungsi } \\
\hline 2.2 & Koordinasi Anggaran \\
\hline 2.3 & Koordinasi Penyusunan Daftar Gaji \\
\hline 3 & Kepegawaian \\
\hline 3.1 & Administrasi Kepegawaian \\
\hline 3.2 & Pengelolaan Dokumentasi Kepegawaian \\
\hline 3.3 & Koordinasi Penilaian Pegawai \\
\hline 3.4 & Pengelolaan Surat \\
\hline 3.5 & Pengelolaan Naskah Dinas \\
\hline 4 & Pengadaan \\
\hline 4.1 & Pengadaan Sarana dan Prasarana \\
\hline 4.2 & Pengelolaan Sarana dan Prasarana \\
\hline 5 & Teknologi Informasi \\
\hline 5.1 & Software Development \\
\hline 5.2 & Server Management \\
\hline 5.3 & Database Management \\
\hline
\end{tabular}

Functional decomposition menggambarkan hubungan antar fungsi bisnis dengan layanan bisnis eksisting serta target yang ada di Dinas Kesehatan Kabupaten Bandung.

Process Flow Diagram menggambarkan aktivitas dari setiap proses bisnis pada Dinas Kesehatan Kabupaten Bandung. Diagram ini juga menggambarkan layanan bisnis target pada functional decomposition.

\section{Data Architecture}

Data architecture merupakan bagian dari fase information system architecture, fase ketiga pada TOGAF ADM. Fase ini digunakan untuk mengidentifikasi entitas data pada suatu organisasi/perusahaan dalam menjalankan fungsinya. Data architecture dibutuhkan untuk mengidentifikasi kebutuhan informasi dan dapat digunakan dalam mempersiapkan application architecture dan technology architetcture. Core artefact pada data architecture yaitu data entity/data component catalog, data entity/business function 
matrix, application/data matrix, class diagram, dan data dissemination diagram.

Data entity/data component catalog berisi entitas data, komponen data logikal, dan komponen data fisikal. Data entity/data component catalog berfungsi untuk mengidentifikasi dan mengelola seluruh data Dinas Kesehatan Kabupaten Bandung.

Data Entity/Business Function Matrix menggambarkan pemetaan antara business function dari Dinas Kesehatan Kabupaten Bandung dengan semua entitas data yang berkaitan dalam perusahaan. Penggambaran data entity/business function matrix menggunakan metode CRUD (create, read, update, dan delete). Create adalah kemampuan untuk membuat entitas baru, read adalah kemampuan untuk mengakses data, update adalah kemampuan dalam memperbaharui data, dan delete adalah kemampuan untuk menghapus data.

Application/Data Matrix menggambarkan hubungan antara aplikasi dengan entitas data yang diakses dan diperbarui oleh Dinas Kesehatan Kabupaten Bandung.
Class diagram bertujuan untuk menampilkan kelas-kelas beserta method dan atributnya yang terdapat pada fungsi kesehatan masyarakat. Penggambaran class diagram pada fungsi kesehatan masyarakat ditunjukkan pada Gambar 3.

Data dissemination diagram bertujuan untuk menunjukkan hubungan antara entitas data, business service, dan komponen aplikasi pada fungsi kesehatan masyarakat.

\section{E. Application Architecture}

Application architecture bertujuan untuk mendefinisikan tipe aplikasi dan integrasi antar tipe-tipe tersebut untuk mendukung proses bisnis Dinas Kesehatan Kabupaten Bandung. Pada application architecture menghasilkan beberapa core artifact yaitu application portfolio catalog, application/organization matrix, application interaction matrix, application/function matrix, application communication diagram, application and user location diagram dan application use case diagram.

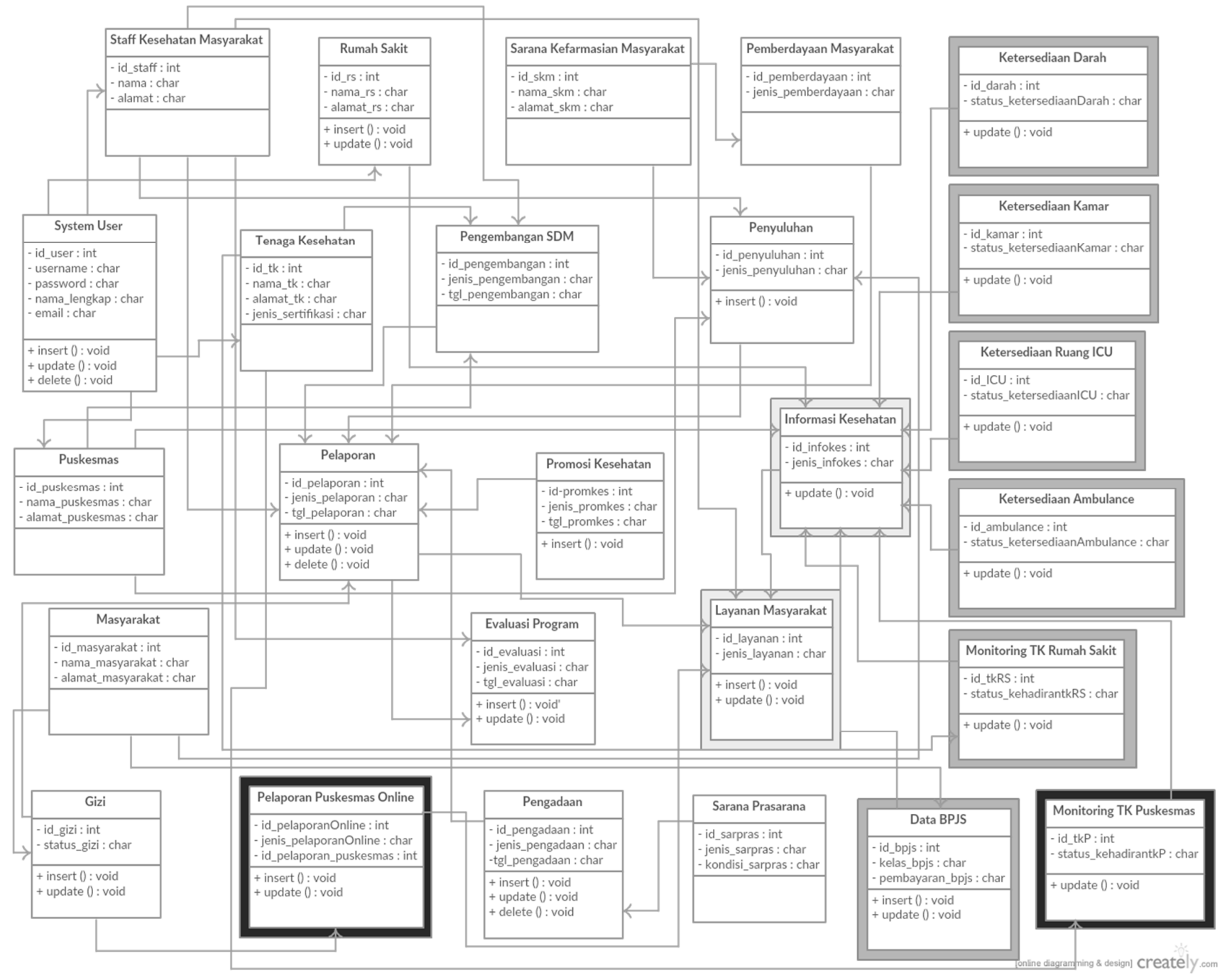

Gambar 3 Class Diagram 
Application portfolio catalog merupakan titik awal dari fase application architecture yang bertujuan untuk mengidentifikasi daftar aplikasi yang digunakan pada fungsi kesehatan masyarakat. Pada application portfolio catalog akan mendefinisikan komponenkomponen aplikasi yang terdiri dari physical application dan logical application.

Application/organization matrix bertujuan untuk menggambarkan hubungan antara aplikasi dan unit organisasi pada fungsi kesehatan masyarakat. Beberapa fungsi dan layanan bisnis yang dilakukan oleh unit organisasi akan didukung oleh aplikasi. Sehingga pemetaan application/organization matrix diperlukan untuk menetapkan penggunaan aplikasi ke unit organisasi pada fungsi bisnis.

Application interaction matrix bertujuan untuk menggambarkan hubungan antar komponen aplikasi physical.

Application/function matrix berfungsi untuk menggambarkan hubungan antar aplikasi dan business funcion yang dimiliki fungsi kesehatan masyarakat. Beberapa fungsi dan layanan bisnis yang dilakukan oleh unit organisasi akan didukung oleh aplikasi. Sehingga pemetaan application/function matrix diperlukan untuk menetapkan penggunaan aplikasi ke fungsi bisnis yang didukung olehnya.

Application communication diagram berfungsi untuk menggambarkan interaksi antar aplikasi, baik logical application component atau physical application component.
Application and user location diagram menunjukkan aplikasi yang digunakan oleh end user. Diagram ini bertujuan untuk menggambarkan lokasi bisnis dimana user biasanya berinteraksi dengan aplikasi beserta lokasi hosting dari infrastruktur aplikasi.

Application use case diagram bertujuan untuk menggambarkan siapa saja yang menggunakan aplikasi serta apa saja yang dapat dilakukan terhadap aplikasi tersebut. Diagram ini mendeskripsikan interaksi antara actors dan peranannya terhadap aplikasi. Gambar 4 menunjukkan application use case diagram pada aplikasi SIK (Sistem Informasi Kesehatan).

\section{F. Technology Architecture}

Fase technology architecture merupakan fase keempat pada TOGAF ADM. Perancangan technology architecture bertujuan untuk mendefinisikan teknologi utama yang dibutuhkan untuk menyediakan lingkungan bagi aplikasi beserta data yang akan dikelola didalam aplikasi tersebut. Pada penelitian ini output yang akan dihasilkan dari technology architecture diantaranya technology standards catalog, technology portfolio catalog, application/technology matrix, environments and locations diagram, dan platform decomposition diagram.

Technology standard catalog digunakan mendokumentasikan standar teknologi yang sudah disepakati untuk digunakan oleh Dinas Kesehatan Kabupaten Bandung.

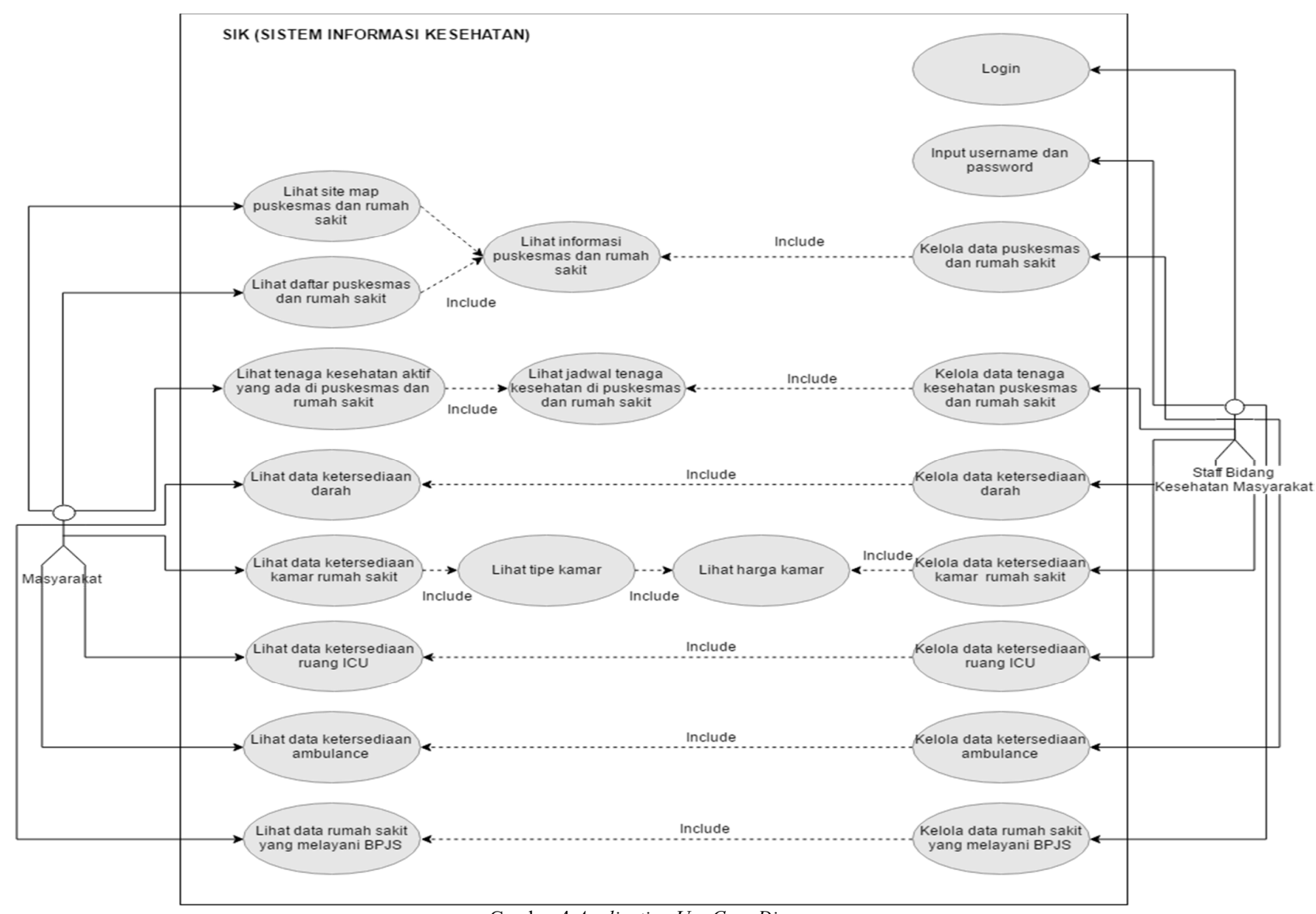

Gambar 4 Application Use Case Diagram 

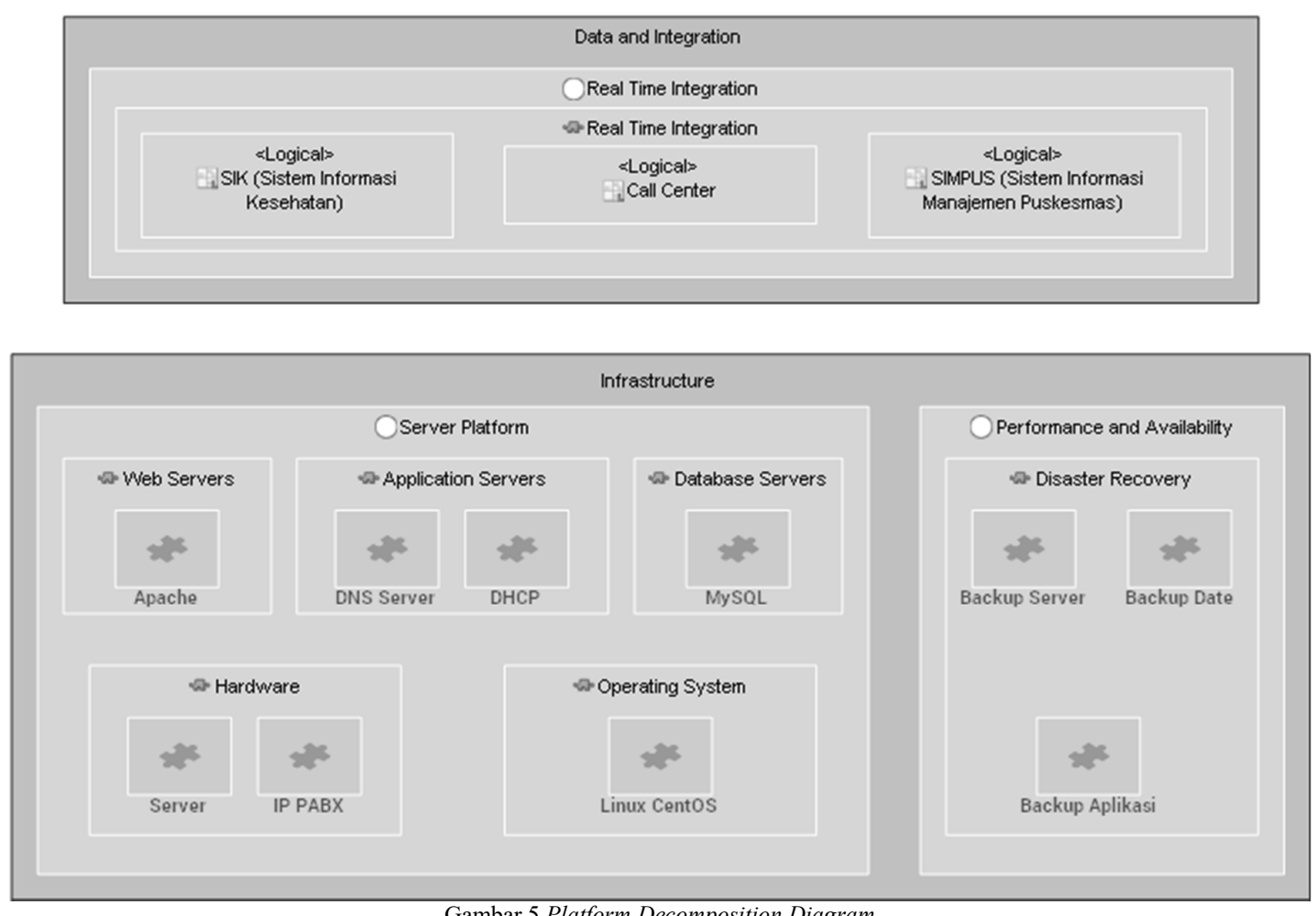

Gambar 5 Platform Decomposition Diagram

Technology portfolio catalog digunakan untuk mengidentifikasi daftar teknologi yang digunakan oleh Dinas Kesehatan Kabupaten Bandung termasuk perangkat keras (hardware), perangkat lunak infrastruktur (infrastructure software), dan perangkat lunak aplikasi (application software).

Application/technology matrix digunakan untuk mendokumentasikan pemetaan aplikasi ke masing-masing komponen teknologi. Environment and location diagram berfungsi untuk menggambarkan di mana saja lokasi teknologi yang digunakan oleh suatu organisasi/perusahaan. Platform decomposition diagram bertujuan untuk menggambarkan standar teknologi yang mendukung arsitektur sistem informasi. Gambar 5 merupakan platform decomposition diagram pada Dinas Kesehatan Kabupaten Bandung.

\section{G. Opportunities and Solutions}

Fase Opportunities and solutions merupakan fase E atau fase kelima pada TOGAF ADM. Fase ini menyampaikan arsitektur dengan memperhitungkan analisis kesenjangan (gap analysis) antara target architecture dan baseline architecture di semua domain arsitektur. Pada penelitian ini output yang dihasilkan diantaranya consolidated gap, solutions, and dependencies matrix; implementation factor assesment; project context diagram; dan benefit diagram.

Consolidated gap, solutions, and dependencies matrix bertujuan untuk mengintegrasikan hasil analisis kesenjangan (gap analysis) dari business architecture, information system architecture, technology architecture, dan menilai solusi potensial serta dependencies.

Implemetation factor assesment bertujuan untuk mendokumentasikan faktor-faktor yang mempengaruhi arsitektur implementation and migration. Matriks ini mencakup daftar faktor yang harus dipertimbangkan, deskripsi, dan deduksi yang menunjukkan tindakan atau hambatan yang harus dipertimbangkan. Tabel III merupakan implementation factor assesment and deduction matrix di Dinas Kesehatan Kabupaten Bandung. Project context diagram digunakan untuk menunjukan lingkup paket kerja yang akan diimplementasikan sebagai bagian dari roadmap yang lebih luas. Benefit diagram digunakan untuk menunjukan peluang yang diidentifikasi dalam definisi arsitektur. Digunakan juga untuk menentukan urutan peluang dan prioritas.

\section{H. Migration Planning}

Fase migration planning merupakan fase keenam pada TOGAF ADM. Perancangan migration planning bertujuan untuk mengintegrasikan roadmap dan implementation and migration plan dengan kegiatan perusahaan lainnya. Pada penelitian ini output yang dihasilkan dari migration planning diantaranya value investasi, risk project IT, business value assessment technique, dan roadmap.

Value investasi digunakan untuk melakukan penghitungan nilai investasi yang akan dikeluarkan oleh perusahaan terhadap pengembangan aplikasi.

Risk project IT digunakan untuk melakukan analisis resiko yang akan dihadapi oleh perusahaan dalam penerapan project IT. Business value assessment technique digunakan untuk menyusun matrix berdasarkan dimensi indeks nilai dan dimensi indeks resiko. Roadmap digunakan untuk memberikan gambaran kerja secara rinci yang akan menjadi acuan tindakan yang harus dilakukan dalam implementasi arsitektur. Tabel IV menunjukkan roadmap Dinas Kesehatan Kabupaten Bandung untuk 4 tahun ke depan.

TABEL III

IMPLEMENTATION FACTOR ASSESMENT AND DEDUCTION MATRIX 


\begin{tabular}{|l|l|l|}
\hline \multicolumn{3}{|c|}{ Implementation Factor Assesment and Deduction Matrix } \\
\hline \multirow{4}{*}{ Risk } & \multicolumn{1}{|c|}{ Factor } & \multicolumn{1}{c|}{ Description } \\
& $\begin{array}{l}\text { Kurangnya } \\
\text { informasi }\end{array}$ & $\begin{array}{l}\text { Kurangnya informasi } \\
\text { dari stakeholder utama } \\
\text { dalam proses } \\
\text { pengembangan aplikasi }\end{array}$ \\
\cline { 2 - 4 } & $\begin{array}{l}\text { Kurangnya } \\
\text { waktu } \\
\text { pengerjaan }\end{array}$ & $\begin{array}{l}\text { Waktu pengerjaan } \\
\text { proyek yang mengalami } \\
\text { keterlambatan dari target } \\
\text { yang telah ditentukan }\end{array}$ \\
\hline \multirow{5}{*}{ Issues } & $\begin{array}{l}\text { Gangguan } \\
\text { listrik }\end{array}$ & $\begin{array}{l}\text { Kemungkinan terjadi } \\
\text { gangguan listrik pada } \\
\text { saat proyek } \\
\text { pengembangan aplikasi }\end{array}$ \\
\cline { 2 - 4 } & Kehilangan data & $\begin{array}{l}\text { Kemungkinan adanya } \\
\text { ancaman virus dan } \\
\text { kejadian tidak terduga } \\
\text { yang menyebabkan } \\
\text { kehilangan data }\end{array}$ \\
\hline \multirow{5}{*}{ Assumptions } & Kurangnya \\
& kesiapan $u s e r$ & $\begin{array}{l}\text { Kurangnya kesiapan user } \\
\text { dalam menggunakan } \\
\text { aplikasi yang } \\
\text { menyebabkan } \\
\text { terganggunya proses } \\
\text { bisnis }\end{array}$ \\
\hline & &
\end{tabular}

\begin{tabular}{|l|l|l|}
\hline \multicolumn{2}{|c|}{ Implementation Factor Assesment and Deduction Matrix } \\
\hline & \multicolumn{1}{|c|}{ Factor } & \multicolumn{1}{c|}{ Description } \\
& $\begin{array}{l}\text { Kemungkinan } \\
\text { pemindahan } \\
\text { server }\end{array}$ & $\begin{array}{l}\text { Server yang lokasinya } \\
\text { berada di vendor } \\
\text { penyedia layanan akan } \\
\text { dipindahkan ke } \\
\text { Diskominfo Kabupaten } \\
\text { Bandung }\end{array}$ \\
\hline \multirow{5}{*}{ Dependencies } & $\begin{array}{l}\text { Ketergantungan } \\
\text { pada APBD }\end{array}$ & $\begin{array}{l}\text { Proyek pengembangan } \\
\text { aplikasi bergantung pada } \\
\text { anggaran yang } \\
\text { ditetapkan pada APBD }\end{array}$ \\
\hline & $\begin{array}{l}\text { Kurangnya komunikasi } \\
\text { antara tim proyek } \\
\text { pengembangan aplikasi } \\
\text { dengan pihak dinkes } \\
\text { yang memungkinkan } \\
\text { terjadinya kegagalan } \\
\text { proyek }\end{array}$ \\
\hline Impacts & $\begin{array}{l}\text { Kurangnya } \\
\text { komunikasi }\end{array}$ & $\begin{array}{l}\text { Penyalahgunaan } \\
\text { teknologi informasi } \\
\text { untuk kepentingan } \\
\text { pribadi }\end{array}$ \\
\hline
\end{tabular}

TABEL IV

ROADMAP

\begin{tabular}{|c|c|c|c|}
\hline \multicolumn{4}{|c|}{ Tahun } \\
\hline $\mathbf{I}$ & II & III & IV \\
\hline $\begin{array}{l}\text { Membangun aplikasi SIMPUS (Sistem } \\
\text { Informasi Manajemen Puskesmas) } \\
\text { berbasis web untuk mempermudah proses } \\
\text { pendataan dan pelaporan layanan } \\
\text { puskesmas }\end{array}$ & \multirow{6}{*}{$\begin{array}{l}\text { Melakukan } \\
\text { pengembangan sistem } \\
\text { SSO (Single Sign On) } \\
\text { untuk efisiensi user } \\
\text { dalam mengakses } \\
\text { semua aplikasi }\end{array}$} & $\begin{array}{l}\text { Membangun aplikasi SIK } \\
\text { (Sistem Informasi Kesehatan) } \\
\text { berbasis mobile untuk } \\
\text { memberikan layanan informasi } \\
\text { kesehatan kepada masyarakat } \\
\text { melalui aplikasi mobile }\end{array}$ & \multirow{5}{*}{$\begin{array}{l}\text { Menyewa perangkat IP PABX } \\
\text { untuk mendukung layanan Call } \\
\text { Center }\end{array}$} \\
\hline $\begin{array}{l}\text { Membangun aplikasi SIK (Sistem } \\
\text { Informasi Kesehatan) berbasis web untuk } \\
\text { memberikan layanan informasi kesehatan } \\
\text { kepada masyarakat }\end{array}$ & & \multirow{4}{*}{$\begin{array}{l}\text { Membangun integrasi antara } \\
\text { aplikasi SIK berbasis mobile } \\
\text { dengan aplikasi SIK berbasis } \\
\text { web }\end{array}$} & \\
\hline $\begin{array}{l}\text { Membangun integrasi antara aplikasi SIK } \\
\text { berbasis web dengan aplikasi SIMPUS } \\
\text { berbasis web }\end{array}$ & & & \\
\hline $\begin{array}{l}\text { Membangun integrasi antara aplikasi SIK } \\
\text { berbasis web dengan aplikasi SIM-RS }\end{array}$ & & & \\
\hline $\begin{array}{l}\text { Membangun integrasi antara aplikasi } \\
\text { SIMPUS berbasis } w e b \text { dengan aplikasi } \\
\text { SIM-RS }\end{array}$ & & & \\
\hline $\begin{array}{l}\text { Membuat SOP (Standar Operasional } \\
\text { Prosedur) aplikasi SIMPUS dan SIK } \\
\text { berbasis web }\end{array}$ & & $\begin{array}{l}\text { Membuat SOP (Standar } \\
\text { Operasional Prosedur) aplikasi } \\
\text { SIK berbasis mobile }\end{array}$ & $\begin{array}{l}\text { Membuat SOP (Standar } \\
\text { Operasional Prosedur) aplikasi } \\
\text { Call Center }\end{array}$ \\
\hline $\begin{array}{l}\text { Menyewa dedicated server untuk aplikasi } \\
\text { SIK dan SIMPUS berbasis web }\end{array}$ & $\begin{array}{l}\text { Menyewa dedicated } \\
\text { server untuk } \\
\text { implementasi sistem } \\
\text { SSO (Single Sign On) }\end{array}$ & $\begin{array}{l}\text { Menyewa dedicated server } \\
\text { untuk aplikasi SIK berbasis } \\
\text { mobile }\end{array}$ & $\begin{array}{l}\text { Migrasi server aplikasi SIMPUS } \\
\text { dan SIK berbasis web dan mobile } \\
\text { serta server SSO dari vendor } \\
\text { penyedia layanan dedicated server } \\
\text { ke Diskominfo Kabupaten Bandung }\end{array}$ \\
\hline
\end{tabular}

\section{KESIMPULAN}


Berdasarkan penelitian yang dilakukan mengenai perancangan enterprise architecture pada fungsi kesehatan masyarakat di Dinas Kesehatan Kabupaten Bandung, dapat diambil kesimpulan bahwa analisis bisnis eksisting dan perancangan proses bisnis target merupakan dasar untuk melakukan perancangan enterprise architecture. Perancangan EA pada fungsi kesehatan masyarakat menggunakan framework TOGAF $\mathrm{ADM}$ dari preliminary phase sampai technology architecture menghasilkan artifak-artifak yang menggambarkan bisnis, sistem informasi, dan teknologi sehingga dapat mendukung proses bisnis yang dirancang. Perancangan tersebut diharapkan dapat meningkatkan kepuasan masyarakat terhadap pelayanan kesehatan dan membuat aktivitas bisnis Dinas Kesehatan Kabupaten Bandung menjadi efektif.

Penelitian ini sebatas perancangan EA pada fungsi kesehatan masyarakat. Penelitian selanjutnya diharapkan dapat dilakukan testing mengenai aplikasi yang diusulkan. Apabila penelitian dianggap layak, maka hasil penelitian diharapkan dapat diimplementasikan di Dinas Kesehatan Kabupaten Bandung.

\section{DAFTAR PUSTAKA}

[1] Ghofar, Z. A. (2011). Perkembangan Teknologi Informatika. 23.

[2] Dinas Kesehatan Kabupaten Bandung. (2016). Laporan Tahunan Tahun 2015. Bandung: Dinas Kesehatan Kabupaten Bandung.

[3] Angraeini, I., Kurniawan, M., \& Mulyana, R. (2015). Perancangan dan Analisis Enterprise Architecture Yayasan Kesehatan (YAKES) TELKOM Pada Domain Arsitektur Teknologi Dengan Menggunakan Framework TOGAF ADM. Jurnal Rekayasa Sistem \& Industri (JRSI), 2(04), 1-8.

[4] Jin, M., Kung, D., \& Peng, W. (2010). Research of Information System Technology Architecture. Industrial and Information Systems , 293-294.

[5] Mezanotte, D. M. (2016). Planning Enterprise Architecture: Creating Organizational Knowledge Using the Theory of Structuration to Build Information Technology . ResearchGate, 2.

[6] Gilliland, S., \& Kotze, P. (2015). Work Level Related Human Factors for Enterprise Architecture as Organisational Strategy . Third International Conference on Enterprise Systems, 43-45.

[7] Franchitti, D. C. (2004). Main Theme High-Level Analysis and Design. 9.

[8] Setiawan, E. B. (2009). Pemilihan EA Framework. SNATI 2009, 6.

[9] The Open Group. (2011). TOGAF. Standard Courseware V9.1 Edition, 10-16. 